\section{Merkel-like cell distribution in the epithelium of the human vagina. An immunohistochemical and TEM study}

\author{
Simona Polakovičová, ${ }^{1}$ \\ Mária Csöbonöyeiová, ${ }^{1}$ Barbora Filová, ${ }^{2}$ \\ Miroslav Borovský, ${ }^{3}$ Ladislav Maršík, ${ }^{3}$ \\ Alena Kvasilová, ${ }^{4}$ Štefan Polák ${ }^{1}$ \\ ${ }^{1}$ Institute of Histology and Embryology, \\ Faculty of Medicine, Comenius \\ University in Bratislava, Slovakia \\ ${ }^{2}$ Institute of Medical Physics, Biophysics, \\ Informatics and Telemedicine, Faculty \\ of Medicine, Comenius University in \\ Bratislava, Slovakia \\ ${ }^{3} 1^{\text {st }}$ Obstetrics and Gynecologic Clinic \\ MFUK with Reproduction Medical \\ Center Hospital of St. Cyril and Metod, \\ Bratislava - Petržalka \\ ${ }^{4}$ Institute of Anatomy, First Faculty of \\ Medicine, Charles University, Prague, \\ Czech Republic
}

\begin{abstract}
Human Merkel cells (MCs) were first described by Friedrich S. Merkel in 1875 and named "Tastzellen" (touch cells). Merkel cells are primarily localized in the basal layer of the epidermis and concentrated in touch-sensitive areas. In our previous work, we reported on the distribution of MCs in the human esophagus, so therefore we chose other parts of the human body to study them. We selected the human vagina, because it has a similar epithelium as the esophagus and plays very important roles in reproduction and sexual pleasure. Due to the fact that there are very few research studies focusing on the innervation of this region, we decided to investigate the occurrence of MCs in the anterior wall of the vagina. The aim of our research was to identify MCs in the stratified squamous non-keratinized epithelium of the human vagina in 20 patients. For the identification of Merkel cells by light microscopy, we used antibodies against simple-epithelial cytokeratins (especially anti-cytokeratin 20). We also tried to identify them using transmission electron microscopy. Our investigation confirmed that $10(50 \%)$ of 20 patients had increased number of predominantly intraepithelial CK20 positive "Merkel-like" cells (MLCs) in the human vaginal epithelium. Subepithelial CK20 positive MLCs were observed in only one
\end{abstract}

patient $(5 \%)$. We tried to identify them also using transmission electron microscopy. Our investigation detected some unique cells that may be MCs. The purpose of vaginal innervation is still unclear. There are no data available concerning the distribution of MCs in the human vagina, so it would be interesting to study the role of MCs in the vaginal epithelium, in the context of innervation and epithelial biology.

\section{Introduction}

\section{Human vagina}

The vagina is a fibromuscular tube, designed as the female copulatory organ ${ }^{1}$ that joins internal reproductive organs to the external environment. It resembles a deflated tube measuring $90.3 \mathrm{~mm}$ in length. ${ }^{2}$ It extends from the vestibule to the cervix of the uterus, anteriorly between the urethra and urinary bladder, and posteriorly between the anal canal and the rectum. ${ }^{1}$ The wall of the vagina microscopically consists of: i) an inner mucosal layer with numerous transverse folds or rugae; ii) an intermediate muscular layer; and iii) an outer adventitial layer. ${ }^{3}$ The inner mucosal layer consists of stratified squamous non-keratinized epithelium and underlying lamina propria with many thin-walled veins. The muscular layer is organized into two indistinct smooth muscle layers, an inner circular and an outer longitudinal layer; ${ }^{3}$ it is innervated by the autonomic nervous system, and contain a great variety of transmitters. ${ }^{4}$ The adventitia is composed of an inner dense and outer loose connective tissue layer, rich in collagen and elastic fibers, contributing to the elasticity and strength of the vaginal wall. ${ }^{3}$ From our point of view, the inner mucosal layer with the epithelium, is the most interesting, especially its anterior wall. The epithelium measures from 0.15 to $0.30 \mathrm{~mm}$ from the top to the bottom (surface to basement membrane). ${ }^{4}$ The mucosal epithelium is hormone-dependent (estrogen) and undergoes changes during the menstrual cycle; after puberty, the epithelium thickens and is rich in glycogen, mostly during the ovulation phase. ${ }^{5}$ A disputable part of the vaginal wall, sensitive to electric stimuli, is located in the anterior part of the vaginal wall. ${ }^{6}$ This sensitive area has been very controversial for more than half a century. ${ }^{5}$ Two researchers, John D. Perry and Beverly Whipple $^{7}$ called it the G-spot. One reason for skepticism is that more than 250 publications have been published, but only a few in peer-reviewed journals. ${ }^{5}$ Hines $^{8}$ in his review article on the G-spot described it as
Correspondence: Simona Polakovičová, Institute of Histology and Embryology, Faculty of Medicine, Comenius University in Bratislava, Sasinkova 4, 81108 Bratislava, Slovakia. Fax: +421.2 .59357538$

E-mail: simona.polakovicova@fmed.uniba.sk

Key words: Merkel cells; human vagina; stratified squamous non-keratinized epithelium; TEM; CK20.

Acknowledgements: This work was prepared in collaboration with 1st Obstetrics and Gynecologic clinic MFUK with Reproduction Medical Center Hospital of St. Cyril and Metod, Bratislava - Petržalka, Slovakia.

Received for publication: 17 July 2017. Accepted for publication: 31 January 2018

This work is licensed under a Creative Commons Attribution-NonCommercial 4.0 International License (CC BY-NC 4.0).

CC Copyright S. Polakovičová et al., 2018 Licensee PAGEPress, Italy

European Journal of Histochemistry 2018; 62:2836 doi:10.4081/ejh.2018.2836

a "modern gynecologic myth". The second reason for skepticism is due to the large differences in vaginal microanatomy between individuals. ${ }^{5}$ Ostrzenski ${ }^{9}$ published an article with anatomically and histologically documented existence of the G-spot and established a hypothesis about a histological tissue that distinguishes the G-spot from the adjacent vaginal and urethral walls. These authors for the first time documented its microscopic architecture as a neurovascular complex with nerve ganglia. ${ }^{9}$

The purpose of vaginal innervation is unclear. ${ }^{10}$ Studies using animal models have revealed that fibers from the pudendal, pelvic, and hypogastric nerves innervate the pelvic organs; ${ }^{11}$ pelvic nerve sensory fibers innervate the vagina. ${ }^{10} \mathrm{~A}$ study by Giraldi ${ }^{12}$ demonstrated the highest concentration of nerve fibers in the vaginal fornix. Estrogen may be responsible for this innervation. According to Mc Kenna, ${ }^{11}$ increased estrogen levels may increase the sensitivity of pudendal nerves. Hilliges et al. ${ }^{13}$ examined six parts of the vaginal mucosa using protein gene product 9.5; they reported that the anterior and distal vaginal walls have increased innervation. ${ }^{13}$ Ting et al. ${ }^{14}$ in a study on rat tissue used the same immunohistochemical marker and compared the innervation of the anterior upper and lower parts of the vagina. Small nerve fibers in the connective tissue under the epithelium were considerably denser in the distal-third of the anterior wall than in the proximal-third. ${ }^{14}$ 
Shafik et al. ${ }^{15}$ stated the existence of a "vaginal pacemaker" that represents the Gspot as a small sensitive area in the vagina.

\section{Merkel cells}

Merkel cells (MCs) are post-mitotic, neuroendocrine cells found in the epidermis of vertebrates. ${ }^{16}$ They were named after the German anatomist and histopathologist Friedrich S. Merkel, who first described these interesting cells in 1875 . They were referred to as "Tastzellen" or "touch cells". ${ }^{17}$ In the glabrous skin, they form clusters connected to nerve endings and are called "touch corpuscles". ${ }^{17}$ Human and animal MCs have been a subject of investigation in many studies for over a century, but their distribution, function and origin still remain unclear. ${ }^{18}$ These rare cells are found in the basal layer of the epidermis and are grouped in touch-sensitive locations in glabrous and hairy skin and in some mucosa. ${ }^{16}$ Their density varies between each anatomical sites. ${ }^{19}$ Mostly, they are concentrated in the palms of the hands, predominantly in the finger pads, and in the soles and toes. ${ }^{20}$ They are also present in the lips, hard palate and gingiva, ${ }^{18}$ esophagus, ${ }^{21,22}$ human eyelid. ${ }^{23}$ The concentration of MCs in the external genitalia has not been studied, but Cold and Taylor ${ }^{24}$ detected some MCs in the male prepuce and in the female clitoris. Two years ago, Schober et $a l .{ }^{25}$ first described MCs in the labia mino$\mathrm{ra}$. The regions richer in MCs are involved in tactile perception, underlining the sensory receptor function of $\mathrm{MCs} .^{26} \mathrm{MCs}$ are more numerous in sun-exposed skin than in covered skin. ${ }^{27}$ Functionally, they are in close contact with nerve fiber endings and form a synapse-like contact zone to receive environmental stimuli. ${ }^{25}$ Some MCs are not associated with nerve axons. ${ }^{28}$ Characteristic features of MCs are: an oval shape, size about $10-15 \mu \mathrm{m}$ in diameter, large, pale, lobulated nucleus, with spikelike cytoplasmic projections which interdigitate with adjacent keratinocytes. ${ }^{29}$ They are attached to neighboring keratinocytes by relatively few, small desmosomes located on the cell body and occasionally on the dendritic-like processes. ${ }^{27}$ Ultrastructurally, they have dense-core secretory granules in the cytoplasm near the nerve fiber connection. ${ }^{27}$ Visualization of MCs by routine light microscopy is not possible, so we need special techniques for their identification. ${ }^{30,31}$ Antibodies against simple-epithelial cytokeratins (CK), especially anti CK type 20 (CK20), provide the highest degree of specificity and allow for the easy identification of MCs by light microscopy. ${ }^{31}$ Other identification method by light microscopy are based on the incorporation of fluorescent FM-dyes (water-soluble, lipophilic, styryl, nontoxic dyes) into living MCs. ${ }^{32}$ The uranaffin reaction has been used in electron microscopy, to detect mammalian intraepithelial MCs. ${ }^{33}$ Uranaffin reaction was introduced as an ultrastructural staining for the localization of adenine nucleotide in organelles storing biogenic amines, ${ }^{33}$ and was used by Beiras et al. ${ }^{34}$ to detect MCs in human epidermis. According to Lucarz and Brand, ${ }^{27} \mathrm{MCs}$ can be functionally classified into subpopulations: mechanoreceptive, endocrine and chemosensitive. They are mechanoreceptors that detect tissue deformation and release various neurotransmitters to nerve endings. ${ }^{27,35}$ Thanks to the dense-core granules in the cytoplasm, they were once considered to be cells of the APUD system (a group of cells with endocrine functions). ${ }^{27}$ They may release substances into blood vessels and to cells in the connective tissue. ${ }^{36}$ According to some scientists, ${ }^{36,37}$ they may play role in the proliferation and differentiation of keratinocytes.

The purpose of our study was to detect MCs in the epithelium of the human vagina using immunohistochemistry with antibodies against simple-epithelial cytokeratins, especially anti-CK20. Subsequently, we tried to identify them using transmission electron microscopy (TEM).

\section{Materials and Methods}

\section{Preparation of samples for immuno- histochemical examination}

Samples of the anterior wall of the human vagina were taken from 20 women. The mean age of the patient was 63 years; the youngest patient was 42-year-old and, the oldest patient was 80 -year-old. Patients underwent trans-abdominal or laparoscopic surgery for various indications at the Department of Gynecology and Obstetrics in Hospital of St. Cyril and Metod in Bratislava, Slovakia. The study protocol was approved by the ethical committee of local hospital, and informed consent was obtained from all patients. Tissue samples from anterior wall of the vagina were fixed in formalin for $24 \mathrm{~h}$, and depending on the length of the vagina were cut into a number of pieces, embedded in paraffin, sectioned into $4 \mu \mathrm{m}$ thick sections, processed by routine histological technique and stained with hematoxylin and eosin. All the samples suit- able for immunohistochemical examination were then sectioned into $5 \mu \mathrm{m}$ thick sections and stained for the expression of antigen CK20. After sectioning they were deparaffinized, rehydrated, immersed in $3 \% \mathrm{H}_{2} \mathrm{O}_{2}$ for block endogenous peroxidases, rinsed in PBS, incubated with proteinase $\mathrm{K}$ (dilution range $100 \mu 1$ proteinase $\mathrm{K}$ in $2.4 \mathrm{ml}$ distilled water) at room temperature for $10 \mathrm{~min}$ and rinsed in PBS. For background blocking, we used solution of $5 \%$ dried milk. Then primary monoclonal antibodies against human CK20 (clone $\mathrm{K}_{\mathrm{s}} 20.8$ ) (Chemicon) were used as a marker for MCs. Sections were incubated for $1 \mathrm{~h}$ with primary antibody (dilution range 1:300) at room temperature, rinsed in PBS, and stained with secondary antibodies (Mouse UnoVue HRP/DAB detection system) (Diagnostic Biosystems) for $15 \mathrm{~min}$. Visualization of the Merkel cells was performed with DAB/plus chromogen. The sections were rinsed in distilled water and stained with Mayer's hematoxylin. For the positive control, we chose samples from human esophagus, where the Merkel cells were detected before. Analysis was performed using a Nikon eclipse $80 \mathrm{i}$ light microscope $(4 \mathrm{x}, 10 \mathrm{x}, 20 \mathrm{x}, 40 \mathrm{x}$ objectives) and images were captured with a Nikon DS-Filcamera. In each patient, we measured the length of each sample under the light microscope (length of the epithelium) and calculated the whole length of the sample. In order to estimate the numerical density of intraepithelial and subepithelial MCs in all samples, the total number of MCs was counted using a graduated ocular.

\section{Preparation of samples for TEM}

For electron microscopy, small blocks were microdissected from paraffin-embedded samples (used for immunohistochemistry) in one case were CK20-positive cells were numerous. Then, these blocks were dewaxed by overnight immersion in xylol, cut into four pieces and rehydrated in phosphate buffer, through a graded series of alcohol dilutions, and washed in saline. The blocks were then refixed in 3\% glutaraldehyde in $0.2 \mathrm{M}$ phosphate buffered saline at room temperature for $4 \mathrm{~h}$ and $1 \%$ osmium tetraoxide in Millonig solution ( $\mathrm{pH} \mathrm{7.3),}$ washed in saline, dehydrated in ethanol, embedded in Durcupan, and cut into semithin and ultrathin sections. Semi-thin sections were stained with toluidine blue and examined with a Nikon eclipse 80i light microscope and a Nikon DS-Filcamera. Ultrathin sections were double stained using uranyl acetate and lead citrate and examined using a TEM (Jeol 1400 plus JMM, voltage $30 \mathrm{keV}$ ). 


\section{Results}

\section{Immunohistochemistry}

CK20 positive Merkel-like cells (MLCs) were identified in 10 of 20 patients $(50 \%)$ in the epithelium of anterior wall of the human vagina. The mean age of the patients was 63 years; the youngest patient was 42-year-old, and the oldest patient was 80 -year-old. Our investigation showed (Figure 1, Table 1) an increased number of CK20 positive MLCs predominantly intraepithelial in the human vaginal epithelium. The cells were dispersed predominantly as a single cell (Figure $2 \mathrm{~A}, \mathrm{~B}$ ), or rarely in clusters (Figure $2 \mathrm{C}$ ) in the lower parts of the epithelial layer.

They were readily visible, because of their oval shape and larger size compared with other epithelial cells. Subepithelial MLCs located in the connective tissue were detected only in one patient (Figure 2D), $5 \%$ of all samples (Figure 1, Table 1). If we evaluate the number of MLCs in all 88 samples of the anterior wall of the human vagina from all 20 patients, then 29 samples contained (34\%) and 59 (66\%) did not contain MLCs. Some samples showed a consid- erable very large number of MLCs (Table 1). The average density of intraepithelial MLCs in all 88 samples of 20 patients was 10 MLCs per $4.94 \mathrm{~cm}$ (average length of the specimen).

\section{Electron microscopy}

Based on their localization and shape in light microscopy, we tried to find similar cells in these same samples using TEM. When we compared cells from immunohistochemistry and TEM, in TEM we found "pale cells" that were oval in shape, measured approximately $10 \mu \mathrm{m}$ in maximal diameter. The cytoplasm appeared as a thin rim encircling the nucleus with dense keratin filaments (Figure $3 \mathrm{~A}, \mathrm{~B}$ ). Cells were localized slightly above the cells of the basal layer of the epithelium (Figure 3 A,B). Nuclei were pale and oval with a predominance of euchromatin and frequently showed small lobulations (Figure $3 \mathrm{~A}, \mathrm{~B}$ ). Cells were connected to other epithelial cells by numerous desmosomes (Figure 3B). At higher magnification, we did not see in the cytoplasm membrane-bound granules typical of MCs, so we are not sure if these "pale cells" were MLCs, but other features were very similar (size, pale nucleus, shape, keratin filaments, desmosomes).

\section{Discussion}

The vagina is lined by a stratified squamous non-keratinized epithelium which varies in thickness and structure throughout woman life. The epithelium is hormone (estrogen) dependent and changes during the menstrual cycle. ${ }^{5}$ Estrogen levels promote stratification, ${ }^{39}$ maturation, proliferation and cellular differentiation ${ }^{40}$ of the epithelium. After puberty, the epithelium

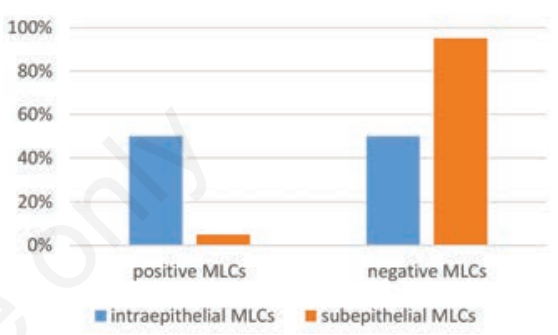

Figure 1. The ratio between positive and negative intraepithelial and subepithelial Merkel-like cells in the samples of human vagina.

Table 1. Total average number of CK20 positive MLCs in the histological section of the human vagina.

\begin{tabular}{|c|c|c|c|c|}
\hline Patients (age) & $\begin{array}{l}\text { Intraepithelial, tn/l } \\
\text { Total number }\end{array}$ & $\begin{array}{l}\text { Intraepithelial, an/l } \\
\text { Average number }\end{array}$ & $\begin{array}{l}\text { Subepithelial, tn/l } \\
\text { Total number }\end{array}$ & $\begin{array}{l}\text { Subepithelial, an/1 } \\
\text { Average number }\end{array}$ \\
\hline $1(61)$ & $54 / 12.2$ & $8 / 1.5$ & $3 / 12.2$ & $2 / 1.5$ \\
\hline $2(66)$ & $0 / 6.7$ & $0 / 1.7$ & $0 / 6.7$ & $0 / 1.7$ \\
\hline $3(66)$ & $0 / 5$ & $0 / 1.25$ & $0 / 5$ & $0 / 1.25$ \\
\hline $4(67)$ & $0 / 4$ & $0 / 1.3$ & $0 / 4$ & $0 / 1.3$ \\
\hline $5(60)$ & $0 / 4.8$ & $0 / 1.2$ & $0 / 4.8$ & $0 / 1.2$ \\
\hline $6(80)$ & $0 / 3.2$ & $0 / 1.1$ & $0 / 3.2$ & $0 / 1.1$ \\
\hline $7(68)$ & $0 / 3.8$ & $0 / 1.9$ & $0 / 3.8$ & $0 / 1.9$ \\
\hline $8(--)$ & $0 / 8$ & 0/1.3 & $0 / 8$ & $0 / 1.3$ \\
\hline $9(59)$ & $12 / 3.5$ & $3 / 0.9$ & $0 / 3.5$ & 0/0.9 \\
\hline $10(77)$ & $9 / 6.5$ & $1 / 1$ & $0 / 6.5$ & $0 / 1$ \\
\hline $11(42)$ & $28 / 9.4$ & $2.8 / 0.94$ & $0 / 9.4$ & $0 / 0.94$ \\
\hline $12(--)$ & $3 / 3.3$ & 1/1.1 & 0/3.3 & $0 / 1.1$ \\
\hline $13(59)$ & $9 / 1$ & $9 / 1$ & $0 / 1$ & $0 / 1$ \\
\hline $14(67)$ & $1 / 6.3$ & $0.25 / 1.6$ & $0 / 6.3$ & $0 / 1.6$ \\
\hline $15(58)$ & $1 / 9.8$ & $0.12 / 1.1$ & $0 / 9.8$ & $0 / 1.1$ \\
\hline $16(55)$ & $0 / 1.3$ & $0 / 1.3$ & $0 / 1.3$ & $0 / 1.3$ \\
\hline $17(69)$ & $0 / 0.8$ & $0 / 0.8$ & $0 / 0.8$ & $0 / 0.8$ \\
\hline $18(59)$ & $86 / 8$ & $12 / 1$ & $0 / 8$ & $0 / 1$ \\
\hline $19(63)$ & $0 / 4.1$ & $0 / 1$ & $0 / 4.1$ & $0 / 1$ \\
\hline $20(56)$ & $1 / 7.1$ & $0.25 / 1.8$ & $0 / 7.1$ & $0 / 1.8$ \\
\hline
\end{tabular}

tn/l, total number of Merkel-like cells /full length of stratified squamous non-keratinized epithelium (cm); an/, average number of Merkel-like cells /average length of stratified squamous non-keratinized epithelium $(\mathrm{cm})$. 
thickens and during ovulation phase of ovarian cycle, and cells contain a lot of glycogen. ${ }^{5}$ Estrogen levels may also participate in the innervation of the vaginal wall ${ }^{10}$ and are responsible for the expansion of the sensitivity and size of perineal nerves. ${ }^{11}$ Nerves that innervate the vaginal wall may be needed for cervical dilatation and vaginal delivery. ${ }^{41,10}$ Hilliges et al. ${ }^{13}$ reported an increased number of nerve fibers in the distal and anterior vaginal wall. It is possible, that nerve fibers terminating in the vaginal mucosa may mediate vaginal sensation and sexual responses, ${ }^{10}$ but there is no evidence that vaginal innervation correlates with sexual function. ${ }^{10}$ The study of MCs in genital organs, especially in the human vagina, may help to clarify sexual arousal, or changes in the vaginal epithelium during the cycle. In the literature, we did not find any information on the incidence of MCs in the human vagina, so it was interesting to study these cells according to their function. MCs have been the subject of investigation in human and animal studies for a long time, but their distribution, origin and function in human skin remain unknown. ${ }^{18}$ The concentration of MCs in the external genitalia has not been studied, but Cold and Taylor ${ }^{24}$ detected some MCs in the male prepuce and in the female clitoris. Structurally, MCs resemble cells of the diffuse endocrine system that are found in the epithelium of the gut and respiratory system. ${ }^{29}$ They are referred to as cells of the amine precursor uptake and decarboxylation system (APUD). ${ }^{27}$ In contrast to normal MCs found in the keratinized epithelium of the skin, MLCs lack any contact with nerve endings, lack cytoplasmic processes, have oval nuclei with many nuclear pores and, have few small desmosomes or hemidesmosomes. ${ }^{29}$ The cytoplasm contains dense-core granules grouped close to the Golgi apparatus. ${ }^{29}$ Our intraepithelial MLCs or "pale" cells also exhibited some of these features. Under higher magnification, we did not see membrane-bound granules; this may have been the effect of the non-routine processing of the tissue or evidence of exocytosis of substances from MLCs. These findings support the theory of Fujita, ${ }^{38}$ concerning a paracrine or neuroendocrine role. If we ignore the mechanoreceptor function of MCs, some authors consider them to be neuroendocrine cells ${ }^{18,29}$ with paracrine functions. ${ }^{29,42}$ Subepithelial MLCs localized in the connective tissue were detected in only one patient ( $5 \%$ of all samples) comparable with the findings of Moll et al. ${ }^{43}$ who detected subepithelial (dermal) MCs in the dermis of plantar skin of human embryos and fetuses at 7-17 gestation weeks. At fetal week 17 , approximately $83 \%$ were located in the epithelium and $17 \%$ in the dermis. These results suggest that some MCs migrate into the dermis and some of them connect with nerves. It supports the "immigration hypothesis", i.e. migration MCs from the epidermis into the dermis. They exist postnatally in the dermis and maybe create reservoir for proliferative cells. The study of MLCs in the human vagina (anterior wall) could be important in two aspects: the first is due to the fact that this area is rela-
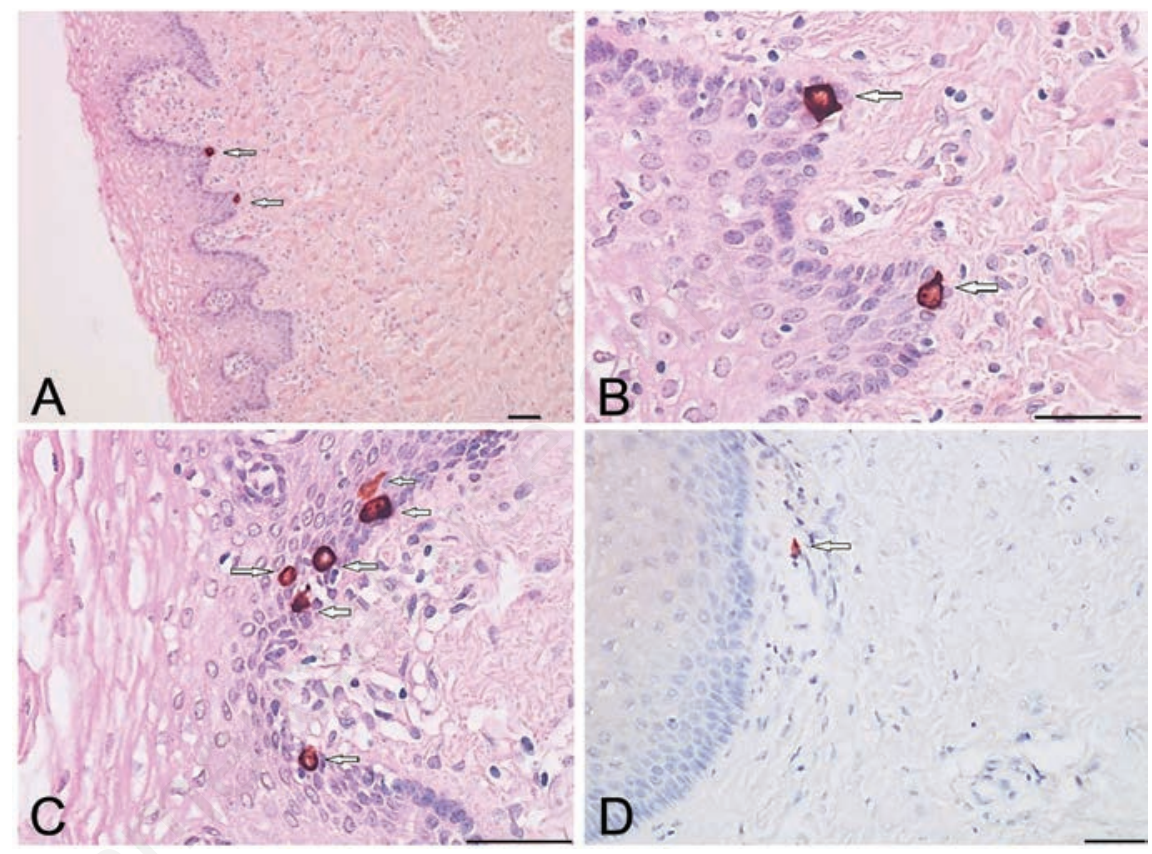

Figure 2. Immunoperoxidase staining (adult human vagina using a monoclonal antibody selective for CK20. A,B) CK20 positive Merkel-like cells are situated as single cell predominantly at lower parts of the epithelial layer (intraepithelial MLCs, white arrows). C) CK20 positive Merkel-like cells are situated rarely in clusters predominantly at lower parts of the epithelial layer (intraepithelial MLCs, white arrows). D) Some CK20 positive Merkel-like cells are located under the epithelium in the connective tissue (subepithelial MLCs, white arrow). Scale bars: $50 \mu \mathrm{m}$.

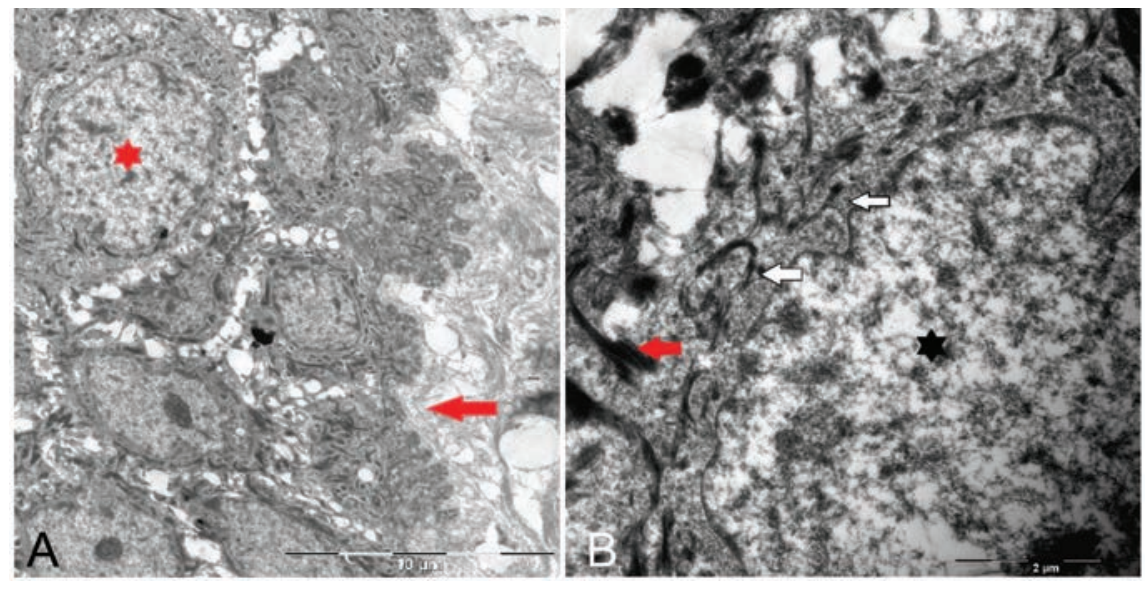

Figure 3. Human adult vagina "pale cells" in the stratified squamous non-keratinized epithelium. A) "Pale cell" with nucleus and thin rim of the cytoplasm (red asterisk), basal lamina of the epithelium (red arrow); original magnification: 2800x. B) Pale nucleus (black asterisk), keratin filaments (white arrows), desmosome (red arrow), original magnification: 14,000x. 


\section{References}

1. Larsson LI, Fahrenkrug J, Schaffalitzky de Muckadell OB. Vasoactive intestinal polypeptide occurs in nerves of the female genitourinary tract. Science 1977;197: 1374-5.

2. Basaran M, Kosif R, Bayar U, Civelek B. Characteristics of external genitalia in preand postmenopausal women. Climacteric 2008;11:416-21.

3. Pawlina W. Histology - a text and atlas with correlated cell and molecular biology. 7th ed. Wolters Kluwer Health; 2016.

4. Baggish MS. Anatomy of the vagina. In: Atlas of pelvic anatomy and gynecologic surgery, Baggish MS, Karram MM, Editors. Elsevier Saunders; St. Louis; 2016.

5. Jannini EA, Amati G, Lenzi A. Histology and immunohistochemical studies of female genital tissue. In: Women's sexual function and dysfunction: Study, diagnosis and treatment. Goldstein I, Meston, CM, Davis RS, Traish AM, Editors. Taylor and Francis; 2006.

6. Weijmar S, van de Wiel WCM, Klatter JA, Sturm BE, Nauta J. Vaginal sensitivity to electric stimuli: theoretical and practical implications. Arch Sex Behav 1989;18:87-95.

7. Perry JD, Whipple B. Pelvic muscle strength of female ejaculators. Evidence in support of a new theory of orgasm. J Sex Res 1981;17:22-39.

8. Hines TM. The G-spot: a modern gynecologic myth. Am J Obstet Gynecol 2001; 185:359-62.

9. Ostrzenski A, Krajewski P, Ganjei-Azar P, Wasiutynski AJ, Scheinberg MN, Tarka S, et al. Verification of the anatomy a newly discovered histology of the G-spot complex. BJOG 2014;1333-41.

10. Pauls R, Mutema G, Segal J, Silva WA, Kleeman S, Dryfhout V, et al. A prospective study examining the anatomic distribution of nerve density in the human vagina. J Sex Med 2006;3:979-87.

11. Mc Kenna KE. The neurophysiology of female sexual function. World J Urol 2002;20:93-100.

12. Giraldi A, Marson L, Nappi R, Pfaus J, Traish AM, Vardi Y, et al. Physiology of female sexual function: Animal models. J Sex Med 2004;1:237-53.

13. Hilliges M, Falconer C, Ekman-Ordeberg $\mathrm{G}$, Johansson O. Innervation of the human vaginal mucosa as revealed by PGP 9.5 immunohistochemistry. Acta Ana (Basel) 1995; 153:119-26.

14. Ting AY, Blacklock AD, Smith PG.
Estrogen regulates vaginal sensory and autonomic nerve density in the rat. Biol Reprod 2004;71:1397-404

15. Shafik A, Sibai OE, Shafik IA. Identification of a vaginal pacemaker: an immunohistochemical and morphometric study. J Obstet Gynaecol 2007; 27:485-8.

16. Boulais N, Misery L. Merkel cells. J Am Acad Dermatol 2007;57:147-65.

17. Merkel F. Tastzellen und Tastkorperchen bei den Hausthieren und beim menschen. Arch Mikrosk Anat 1875;11:636-52.

18. Boot PM, Rowden G, Walsh N. The distribution of Merkel cells in human fetal and adult skin. Am J Dermatopathol 1992;14: 391-6.

19. Moll I, Roessler M, Brandner JM, Eispert A, Houdek P, Moll R. Human Merkel cells -aspects of cell biology, distribution and functions. Eur J Cell Biol 2005;84:259-71.

20. Hartschuh W, Grube D. The Merkel cell: A member of the APUD cell system. Fluorescence and electron microscopic contribution to the neurotransmitter function of the Merkel cell granules. Arch Dermatol Res 1979;265:115-22.

21. Polakovičová S, Mikušová M, Polák Š. Merkel cells in the stratified squamous nonkeratinized epithelium of the human oesophagus. Biologia 2013;68: 743-6.

22. Harmse JL, Carey F, Baird SR, Craig SR, Christie KN, Hopwood D, et al. Merkel cells in the human oesophagus. J Pathol 1999;189:176-9.

23. May CA, Osterland I. Merkel cell distribution in the human eyelid. Eur J Histochem 2013;57:e33.

24. Cold CJ, Taylor JR. The prepuce. Br J Urol 1999;8:34-44.

25. Schober JM, Martin-Alguacil N, Cooper RS, Aardsma N, Mayoglou L, Litvin Y, et al. Identification of Merkel cells in the labia minora skin of prepubertal girls. J Genit Syst Disor 2016;5:1-5.

26. Munde PB. Pathophysiology of Merkel cells. J Oral Maxillofac Pathol 2013;17: 408-12.

27. Lucarz A, Brand G. Current considerations about Merkel cell. Eur J Cell Biol 2007;86:243-51.

28. Garant PR, Feldman J, Cho MI, Cullen MR. Ultrastructure of Merkel cells in the hard palate of the squirrel monkey (Saimiri sciureus). Am J Anat 1980;157: 155-67.

29. Halata Z, Grim M, Bauman KI. Friedrich Sigmund Merkel and his "Merkel cell", morphology, development, and physiology: review and new results. Anat Rec A Discov Mol.Cell Evol Biol 2003;271: 225-39.

30. Crowe R, Whitear M. Quinacrine fluores- cence of Merkel cells in Xenopus leavis. Cell Tissue Res 1978;190:273-83.

31. Moll I, Kuhn C, Moll R. Cytokeratin 20 is a general marker of cutaneous Merkel cells while certain neuronal proteins are absent. J Invest Dermatol 1995;104:910-5.

32. Fukuda J, Ishimine H, Masaki Y. Longterm staining of live Merkel cells with FM dyes. Cell Tissue Res 2003;311:325-32.

33. Richards J, Prada DM. Uranaffin reaction: a new cytochemical technique for the localization of adenine nucleotides in organelles storing biogenic amines. J Hystochem Cytochem 1997;25:1322-36.

34. Beiras A, Garcia-Caballero T, Gallero R, Roson E. Staining of neuroendocrine Merkel cells of human epidermis using the uranaffin reaction. J Invest Dermatol 1987;89:366-8.

35. Haeberle H, Fujiwara M, Chuang J, Medina MM, Panditrao MV, Bechstedt S, et al. Molecular profiling reveals synaptic release machinery in Merkel cells. Proc Natl Acad Sci USA 2004;101:503-8.

36. Tachibana T. The Merkel cell: recent findings and unresolved problems. Arch Histol Cytol 1995;58:379-96.

37. Kim DK, Holbrook KA. The appearance, density, and distribution of Merkel cells in human embryonic and fetal skin: their relation to sweat gland and hair follicle development. J Invest Dermatol 1995;104: 411-6.

38. Fujita T. Concept of paraneurons. Arch Histol Jpn 1977;40(Suppl):1-12.

39. Blakeman PJ, Hilton P, Bulmer JN. Oestrogen and progesterone receptor expression in the female lower urinary tract, with reference to oestrogen status. BJU Inter 2000;86:32-8.

40. Lara LA, Ribeiro A, Rosa Jc, Chaud F, Marcos F, Moireles AR, et al. Menopause leading to increased vaginal wall thickness in women with genital prolapse: Impact on sexual response. J Sex Med 2009;6:3097110.

41. Stjernholm Y, Sennstrom M, Granstrom L, Ekman G, Johansson O. Protein gene product 9.5-immunorective nerve fibers and cells in human cervix of late pregnant, postpartal and non-pregnant women. Acta Obstet Gynecol Scand 1999;78:299-304.

42. Hartschuh W, Weihe E. Pancreastatin-like immunoreactivity in epidermal Merkel cells of pig and man. Neurosci Lett 1989;98:258-63.

43. Moll I, Moll R, Werner W, Franke W. Formation of edpidermal and dermal Merkel cells during human fetal skin development. J Invest Dermatol 1986;87: 779-87. 